\title{
The effectiveness of the use of a biologically active additive ekobentokorm in the diets of cattle
}

\author{
Galina Zelenkova ${ }^{1}$, Sergei Tresnitskii ${ }^{1}$, Pavel Bykadorov ${ }^{2}$, Anna Pecinovsky $^{2}$, Aleksandr \\ Yenin $^{2}$, and Alexey Zelenkov ${ }^{3,1, *}$ \\ ${ }^{1}$ Don State Technical University, sq. Gagarina, 1, 344003 Rostov-on-Don, Russia \\ ${ }^{2}$ «Luhansk State Agrarian University», the town LNAU, 1, 91008 Lugansk city, Lugansk People's \\ Republic \\ ${ }^{3}$ Ministry of Agriculture and Food of the Rostov region, Krasnoarmeyskaya st., 33, 344010 Rostov- \\ on-Don, Russia
}

\begin{abstract}
Studies have established the effect of ekobentokorm (TU 9283-199-10514645-13-2013) on the metabolism of cows and the natural resistance of young black-and-white breed. The physiological state of cows was assessed by morphological and biochemical studies of blood, in which changes in the body's metabolic processes were tracked in dynamics according to the following indicators: the number of red blood cells and hemoglobin level, total protein and protein fractions, glucose, urea, aminotransferases (AST, ALT), total calcium and inorganic phosphorus, trace elements $(\mathrm{Mg}, \mathrm{Zn}, \mathrm{Fe}, \mathrm{Cu})$ and carotene. The indicators characterizing the natural resistance of young animals were studied: red blood cells, white blood cells, hemoglobin, color index, total protein and protein fractions, phagocytic activity of neutrophil granulocytes, bactericidal and lysozyme activity of blood serum, the content and concentration of T-and B-lymphocytes, the level of circulating immune complexes (CIC). As a result of the conducted research, it was found that ekobentokorm has high biological activity, improves morphological and biochemical parameters of cows blood, and also increases milk productivity. It has a pronounced stimulating effect on the immunocompetent systems of the body of young animals, as a result of which the level of non-specific protection of the animal increases.
\end{abstract}

\section{Introduction}

Natural minerals and their use in the diets of farm animals and poultry, both in pure form and in the production of biologically active feed additives, premixes, top dressing, mixed feeds - a modern trend in animal and poultry feeding. Due to their good adsorption, catalytic, ion-exchange properties, flowability, density, and roughness, they are used as a filler in feed additives. Also, the presence of easily digestible mobile forms of a number of

\footnotetext{
* Corresponding author: zelenkovalex@rambler.ru
} 
macro - and microelements in their composition contributes to the activation of physiological, biochemical and immune processes in the body of animals and poultry.

The practice of using ekobentokorm (TU 9283-199-10514645-13-2013) in the feeding of farm animals and poultry has revealed the effectiveness of this top dressing, which is expressed in increasing productivity indicators.

The purpose of our research was to determine the effect of ekobentokorm (TU 9283-199-10514645-13-2013) on the metabolism of cows and the natural resistance of young black-and-white cattle.

\section{Materials and Methods}

The influence of ekobentokorm (TU 9283-199-10514645-13-2013) on the metabolic parameters of cows and the natural resistance of young black-and-white cattle was established by conducting a series of scientific and economic experiments on the basis of dairy farms in the Rostov region.

The first series of experiments was conducted on black-and-white cows that were 2-4 months of lactation. The animals used in the experiment were divided into two groups of 30 animals each, taking into account body weight, age and productivity. All the experimental cows were clinically healthy.

The second series of experiments was conducted on intact animals (calves) of 3.5-4 months of age of a black-and-white breed. According to the principle of analogues, two groups of 10 calves each were formed.

The control groups were on the feed ration used in the farm, and the animals of the experimental groups were additionally introduced into the main ration ekobentokorm (TU 9283-199-10514645-13-2013) according to the scheme of the experiment (Table 1).

Table 1. Scheme of scientific and economic experience

\begin{tabular}{|c|c|c|c|c|c|}
\hline Group & $\begin{array}{l}\text { Type of } \\
\text { animal }\end{array}$ & $\begin{array}{l}\text { Age, } \\
\text { month. }\end{array}$ & $\begin{array}{l}\text { Number of } \\
\text { animals }\end{array}$ & $\begin{array}{c}\text { Dose input } \\
\text { ekobentokorma }\end{array}$ & $\begin{array}{l}\text { The period } \\
\text { of } \\
\text { experience, } \\
\text { days }\end{array}$ \\
\hline \multicolumn{6}{|c|}{ The first series of experiments } \\
\hline control & $\begin{array}{l}\text { black-and- } \\
\text { white } \\
\text { cows }\end{array}$ & $\begin{array}{l}2-4 \text { month } \\
\text { of lactation }\end{array}$ & 30 & the main diet & 90 \\
\hline experienced & $\begin{array}{l}\text { black-and- } \\
\text { white } \\
\text { cows }\end{array}$ & $\begin{array}{l}2-4 \text { month } \\
\text { of lactation }\end{array}$ & 30 & $\begin{array}{c}\text { the main diet }+3 \% \\
\text { ekobentokorma to dry } \\
\text { matter }\end{array}$ & 90 \\
\hline \multicolumn{6}{|c|}{ The second series of experiments } \\
\hline control & $\begin{array}{l}\text { black-and- } \\
\text { white } \\
\text { calves }\end{array}$ & $3,5-4$ & 10 & the main diet & 60 \\
\hline experienced & $\begin{array}{l}\text { black-and- } \\
\text { white } \\
\text { calves }\end{array}$ & $3,5-4$ & 10 & $\begin{array}{l}\text { the main diet }+1 \% \\
\text { ekobentokorma from } \\
\text { the mass of feed }\end{array}$ & 60 \\
\hline
\end{tabular}

The content of farmyard animals, watering from autopilot, feeding three times: in the morning asked half the daily requirement, succulents, day - of- rest of the silo, in the evening forage. Concentrated feed was given before each milking. The diets were balanced in basic nutrients and met the requirements.

The cows of the control group received the feed of the main diet, the experimental group of animals with concentrates was additionally fed ekobentokorm (TU 9283-199-10514645-13-2013) at the rate of 3\% of the dry matter of the diet. 
For three months the physiological state of the cows was assessed by morphological and biochemical blood tests, which tracked the dynamics of changes in the metabolic processes of the organism of cows on the following parameters: the number of red blood cells and hemoglobin, total protein and protein fractions, glucose, urea, level of transaminases (AST, ALT), total calcium and inorganic phosphorus, as well as some trace elements ( $\mathrm{Mg}, \mathrm{Zn}, \mathrm{Fe}$, $\mathrm{Cu}$ ) and carotene.

To study the indicators of natural resistance of the body of young animals, blood was examined, which was taken from 5 animals from each group three times - at the beginning of the experiment, on days 30 and 60, and changes in the body of calves were tracked in dynamics according to the following indicators: red blood cells, white blood cells, hemoglobin, color index, total protein and protein fractions. In addition, the phagocytic activity of neutrophil granulocytes, the bactericidal and lysozyme activity of blood serum, the percentage ratio and concentration of T-and B-lymphocytes, as well as the level of circulating immune complexes (CIC) were determined.

The digital material obtained in the experiments was subjected to biometric processing.

\section{Results}

\subsection{The first series of experiences}

The physiological state of the animals, estimated by morphological and biochemical parameters of the blood, which were monitored in dynamics, is presented in Table 2.

Table 2. The effect of ekobentokorm on the biochemical parameters of the blood of cows $(\mathrm{M} \pm \mathrm{m} ; \mathrm{n}=60)$

\begin{tabular}{|c|c|c|c|c|}
\hline \multirow[t]{2}{*}{ Indicator } & \multicolumn{2}{|c|}{ Control group } & \multicolumn{2}{|c|}{ Experimental group } \\
\hline & after 60 days & after 90 days & after 60 days & after 90 days \\
\hline Total protein, $\mathrm{g} / \mathrm{l}$ & $86.4 \pm 13.6$ & $90.1 \pm 11.9$ & $89.6 \pm 13.5$ & $98.3 \pm 18.1^{*}$ \\
\hline Protein fractions, $\%$ : albumin & $42.4 \pm 5.5$ & $39.2 \pm 6.0$ & $43.7 \pm 5.9 *$ & $46.3 \pm 6.7 *$ \\
\hline$\alpha$-globulins & $12.1 \pm 1.1$ & $11.5 \pm 0.8$ & $14.0+2.6$ & $16.7 \pm 2.8$ \\
\hline$\beta$-globulins & $6.9 \pm 1.3$ & $10.2 \pm 2.8$ & $12.0+1.7$ & $12.9 \pm 2.4$ \\
\hline$\gamma$-globulins & $38.6 \pm 5.1$ & $39.1 \pm 3.6$ & $30.3 \pm 6.2$ & $24.1 \pm 3.2$ \\
\hline Glucose, mmol/1 & $1.94 \pm 0.51$ & $1.83 \pm 0.4$ & $2.38 \pm 0.5$ & $2.5 \pm 0.8$ \\
\hline Urea, $\mathrm{mmol} / \mathrm{l}$ & $7.8 \pm 0.8$ & $6.3+0.4$ & $4.8 \pm 0.6$ & $6.5 \pm 0.7$ \\
\hline AST, units/ml & $39.0 \pm 4.8$ & $41.2 \pm 6.3$ & $34.5 \pm 2.9$ & $38.7 \pm 3.6$ \\
\hline ALT, units/ml & $14.3 \pm 3.5$ & $24.4 \pm 5.2$ & $16.6 \pm 4.8$ & $19.9 \pm 2.7$ \\
\hline Total calcium, mmol/l & $1.68 \pm 0.3$ & $1.9 \pm 0.34$ & $1.84 \pm 0.55$ & $2.3 \pm 0.7$ \\
\hline Inorganic phosphorus, mmol/l & $2.8 \pm 0.4$ & $2.7 \pm 0.39$ & $2.1 \pm 0.44$ & $2.14 \pm 0.49$ \\
\hline Iron, $\mathrm{mmol} / \mathrm{l}$ & $22.6 \pm 3.5$ & $24.0 \pm 2.6$ & $27.4 \pm 4.0 *$ & $28.8 \pm 3.6^{*}$ \\
\hline Zinc, mmol/1 & $12.4 \pm 0.9$ & $14.6 \pm 2.0$ & $16.5 \pm 2.4$ & $17.3 \pm 3.2$ \\
\hline Copper, mmol/1 & $14.6 \pm 4.5$ & $13.9 \pm 5.1$ & $14.0 \pm 4.7$ & $14.9 \pm 2.5$ \\
\hline Manganese, $\mathrm{mmol} / \mathrm{l}$ & $1.12 \pm 0.4$ & $1.0 \pm 0.35$ & $1.09 \pm 0.8$ & $1.06 \pm 0.3$ \\
\hline Carotene, microns/l & $0.57+0.04$ & $0.42 \pm 0.03$ & $0.49 \pm 0.06$ & $0.5 \pm 0.02$ \\
\hline
\end{tabular}

$* \mathrm{P}<0.05$

Studies have shown that ekobentokorm included in the composition of the diet of experimental animals, has a pronounced pharmacological activity.

The use of ekobentokorm had a positive impact on the biochemical homeostasis of experimental animals. In the picture of red blood of cows, a significant $(\mathrm{P}<0.05)$ increase in red blood cells and hemoglobin was noted. At the same time, the level of hemoglobin in 
the first month of the experiment increased by $12.4 \%$ relative to the background values, and after 60 and 90 days its concentration increased to $14.7 \%$ and $16.1 \%$, respectively (106.0 $\pm 41.2 \mathrm{~g} / 1$ and $107.4 \pm 38.5 \mathrm{~g} / \mathrm{l}$ versus $92.4 \pm 29.7 \mathrm{~g} / 1$ of the background values). The increase in the number of red blood cells in experimental animals over the entire study period varied in the range of $8.6-11.7 \%$.

In the control group, there was a slight increase in the level of hemoglobin (by 4.7\%) while maintaining the initial (background) number of red blood cells (6.21 $\pm 0.9 \times 1012)$. However, these results are unreliable.

The total protein content in the blood serum increased by $2.8-12.7 \%$ and amounted to $98.3 \pm 18.1 \mathrm{~g} / \mathrm{l}$ by the end of the experimental period against $87.2 \pm 10.4 \mathrm{~g} / \mathrm{l}$ of background indicators and $90.1 \pm 11.9 \mathrm{~g} / \mathrm{l}$ of control animals. Moreover, the greatest difference in the protein content in the groups was observed from the second month of the study (the difference in indicators was $9.1 \%$, differing in the reliability $(\mathrm{P}<0.05)$ of the results).

The number of albumins in the blood serum before the experiment, on average for the groups, was $40.1 \%$.

With the introduction of ekobentokorm, an increase in the level of this fraction was noted in experienced cows after 60 days - by $8.9 \%$, and after 90 days - by $15.5 \%$. At the same time, the reliability of the results on the level of albumins was already evident from the second month of ekobentokorm use $(\mathrm{P}<0.05)$.

There was a decrease in gamma-globulins, which did not go beyond the limits of physiological fluctuations. According to the level of other globulin fractions, the trend in the normalization of indicators and the general stabilization of the proteinograms of cows in the experimental group was monitored.

Thus, it is possible to note the activation of the processes of biological protein synthesis and, first of all, its albumin fraction under the conditions of the use of ekobentokorm, the metabolic activity of which is due to the content of a wide range of macro-and microelements and the physical and chemical features of the structure. Of the trace elements that make up the ekobentokorm, the nucleic exchange, which determines the further stage of protein metabolism - protein biosynthesis, can include $\mathrm{Mg}, \mathrm{Zn}$, and $\mathrm{Cu}$ ions. The concentration of these elements in the range of $0.003-0.125 \mathrm{mg}^{\circ}$ is quite sufficient for the manifestation of the biological activity of ekobentokorm. Soluble in the aqueous phase, easily exchangeable metal cations are involved in the regulation of metabolism, enhancing the protein synthesis function of the liver.

In the control, the level of $\beta$-globulins was quite low for this physiological state of the animals. With a simultaneous decrease in albumins in the proteinograms of control cows, the body turns on a system of compensatory selective increase in the gamma-globulin fraction, the level of which increased by $23.3 \%$ by the end of the experimental period.

The main indicator of carbohydrate metabolism - glucose, in the experimental group increased during the study period by 1.4 times compared to control animals and by 1.8 times compared to background studies.

The results of the studies showed that the use of ekobentokorm in the diet of cows affected the assimilation of mineral elements. Calcium metabolism in the body of cows occurs most intensively, especially with the intensity of physiological processes (lactation, pregnancy), as a result of which there are often deficient conditions for this mineral. And since the exchange of calcium in the body is directly related to the exchange of phosphorus, violations of the $\mathrm{Ca}: \mathrm{P}$ ratio often lead to severe disorders of mineral metabolism and the occurrence of diseases of an osteodystrophic nature. In our case, the ratio of $\mathrm{Ca}$ to $\mathrm{P}$ at the beginning of the experiment was 0.56 . The imbalance was associated with a low calcium content $(1.57 \pm 0.2 \mathrm{mmol} / \mathrm{l})$. The level of phosphorus in the blood serum of cows before the experiment was at the upper limits of the physiological norm $(2.4 \pm 0.25 \mathrm{mmol} / \mathrm{l})$. However, after 60 days of ekobentokorm application, the calcium content in the blood of 
experimental cows increased by $17.7 \%$ (against $7.0 \%$ of the control group), and by the end of the experiment - by $46.5 \%$, reaching physiological limits. The phosphorus level, on the contrary, gradually decreased, falling to a value of $2.1-2.14 \pm 0.49 \mathrm{mmol} / \mathrm{l}$. At the same time, the $\mathrm{Ca}: \mathrm{P}$ ratio changed upward to 1.07 .

In the intact animals (control group), the total calcium level remained low $(1.9 \pm 0.34$ $\mathrm{mmol} / \mathrm{l}$ or $76.6 \%$ of the physiological norm), and the phosphorus concentration was high $(2.7 \pm 0.39 \mathrm{mmol} / \mathrm{l}$ at the upper physiological values of $2.3 \mathrm{mmol} / \mathrm{l})$.

The difference in the content of trace elements in the cows of the experimental and control groups was more significant. Thus, iron in the blood of experimental cows by the end of the study increased by $39.9 \%$, zinc-by $24.5 \%$, copper-by $11.2 \%$. In the control group, these indicators remained at the level of background studies (the difference by the end of the experiment ranged from 3.7-5.0\%). Only in terms of iron levels, the values were higher (116.6\%), but the reliability of the results was not noted.

The level of magnesium and carotene ekobentokorm significant influence not provided.

During the entire experimental period, the concentration of iron, zinc and copper in the body of cows of the experimental group had higher values in comparison with the control.

Sorption, ion-exchange properties of ekobentokorm, the possibility of replenishing diets with macro-and microelements, which, in turn, are included in the redox reactions of the body as co-enzymes, contribute to the immobilization of enzyme systems, lead to the activation of metabolic processes, more efficient use of nutrients in the diet, including the synthesis of milk.

Thus, when studying the dynamics of the average daily milk yield in experimental animals, the effect in the difference between their milk yields and those of cows in the control group was noted at the end of the first month of feeding ekobentokorm and amounted to $0.87 \pm 0.02 \mathrm{~kg}$ of milk per day or $4.73 \%$. In the second month of the experiment, the difference in the average daily milk yield was $1.14 \pm 0.03 \mathrm{~kg}$ or 6.8 . On average, the amount of milk in experimental cows increased by $7.3-7.8 \%$ during the experimental period.

\subsection{The second series of experiments}

The obtained data from the study of calves ' blood by morphological and biochemical parameters are presented in (Table 3).

Table 3. Effect ekobentokorma on morphological and biochemical indices of blood of calves

$(\mathrm{M} \pm \mathrm{m} ; \mathrm{n}=10)$

\begin{tabular}{|l|c|c|c|c|}
\hline \multirow{2}{*}{ Indicator } & \multicolumn{2}{c|}{ Control group } & \multicolumn{2}{c|}{ Experimental group } \\
\cline { 2 - 5 } & after 30 days & after 60 days & after 30 days & after 60 days \\
\hline White blood cells, $10^{9} / 1$ & $8.7 \pm 1.4$ & $8.6+0.99$ & $9.11 \pm 2.3$ & $9.4 \pm 1.6$ \\
\hline Red blood cells, $10^{12} / 1$ & $5.8 \pm 0.82$ & $6.01 \pm 0.7$ & $5.97 \pm 1.0$ & $6.86 \pm 0.85$ \\
\hline Hemoglobin, g/1 & $91.2 \pm 11.5$ & $93.9 \pm 12.1$ & $106.3 \pm 9.9$ & $108.5 \pm 14.2^{*}$ \\
\hline Colour index & 0.93 & 0.92 & 1.05 & 0.94 \\
\hline Basophils & 0 & 0 & 0 & 0 \\
\hline Eosinophils & $2.0 \pm 0.04$ & $2.6 \pm .09$ & $0.7 \pm 0.01$ & $1.8 \pm 0.06$ \\
\hline Young neutrophils & 0 & 0 & 0 & 0 \\
\hline Rod-shaped neutrophils & $1.4 \pm 0.06$ & 0 & $3.5 \pm 0.11$ & 0 \\
\hline Segmental neutrophils & $26.3 \pm 3.2$ & $21.0 \pm 3.8$ & $31.4 \pm 4.4$ & $37.0 \pm 2.6$ \\
\hline Lymphocytes & $68.7 \pm 7.7$ & $75.3 \pm 11.2$ & $62.7 \pm 9.4$ & $58.7 \pm 5.8$ \\
\hline Monocytes & $1.6 \pm 0.02$ & $1.1 \pm 0.02$ & $1.7 \pm 0.04$ & $2.5 \pm 0.03$ \\
\hline Total protein, g/1 & $63.4 \pm 6.6$ & $68.0 \pm 7.3$ & $71.3 \pm 9.5$ & $72.4 \pm 7.5 *$ \\
\hline albumin & $46.7 \pm 3.9$ & $43.4 \pm 5.1$ & $49.3 \pm 6.0$ & $47.1 \pm 5.8$ \\
\hline$\alpha$ - globulins & $13.6 \pm 2.0$ & $11.8 \pm 0.9$ & $11.9 \pm 3.4$ & $11.0 \pm 2.4$ \\
\hline
\end{tabular}




\begin{tabular}{|l|c|c|c|c|}
\hline$\beta$ - globulins & $18.8 \pm 3.4$ & $18.0+4.2$ & $14.2 \pm 1.5$ & $12.2 \pm 0.87$ \\
\hline$\gamma$ - globulins & $20.9 \pm 2.8$ & $26.8 \pm 4.4$ & $24.6 \pm 5.2$ & $29.7 \pm 7.1$ \\
\hline
\end{tabular}

Background studies found that the peripheral blood parameters of young cattle in the groups differed little from each other. Insufficient values for the physiological state of calves of this age group include the concentration of hemoglobin $(97 \%$ of the lower normal values) and total protein, which is reduced in all experimental animals, on average, by $10.5 \%$.

The level of red blood cells during the experiment tended to increase in both groups, but in experimental animals this increase is more pronounced $\left(6.86 \pm 0.85 \times 10^{12} / 1 \mathrm{vs}\right.$. $6.01 \pm 0.7$ $\times 10^{12} / 1$ or $117.6 \%$ vs. $103.0 \%$ relative to background values). A similar trend was observed with respect to the content of hemoglobin. Thus, in the calves of the experimental group, the hemoglobin level was significantly higher by $15.5 \%$ than in the control animals ( $P$ $<0.05$ ).

The use of ekobentokorm in the diets of calves did not significantly affect the level of white blood cells. However, the average white blood cell count in $1 \mathrm{mcl}$ of blood in experimental animals was $9.3 \%$ higher by the end of the experiment $\left(9.4 \pm 1.6 \times 10^{9} / 1\right.$ vs. $\left.8.6 \pm 0.99 \times 10^{9} / 1\right)$. The fluctuations in the groups were $7.5-17.4 \%$ of the average level of the physiological norm and $4.8-14.6 \%$ relative to the background indicators.

An increase in the level of white blood cells in combination with an increase in the number of red blood cells and hemoglobin in the experimental group may indicate the activation of the hematopoietic organs. This assumption is also confirmed by the leukograms of experimental calves, in which the dynamics of normalization of the percentage of differential white blood cells was traced.

The presence of a significant difference $(\mathrm{P}<0.05)$ in the indicators of total protein and protein fractions in the calves of the experimental group indicates a positive effect of ekobentokorm feed on protein metabolism. During the experiment, the level of total protein in the experimental animals increased by $9.4 \%$.

Relative to the control calves, this indicator increased by $6.5 \%$. In addition, the experimental animals showed a tendency to increase the gamma-globulin fraction ( $29.7 \pm 7.1 \%$ vs. $26.8 \pm 4.4 \%$ in comparison with the control).

The improvement of the functions of the hematopoietic organs had an impact on the level of natural resistance of the calves receiving ekobentokorms.

The results of our studies indicate that the use of ekobentokorm increased the cellular immunity of calves (Table 4).

Table 4. The effect of ekobentokorm on the immunity indicators of calves ( $M \pm m ; n=10)$

\begin{tabular}{|c|c|c|c|c|}
\hline \multirow{2}{*}{ Indicator } & \multicolumn{2}{|c|}{ Control group } & \multicolumn{2}{c|}{ Experimental group } \\
\cline { 2 - 5 } & after 30 days & after 60 days & after 30 days & after 60 days \\
\hline Phagocytic activity, \% & $52.3 \pm 2.14$ & $26.0 \pm 2.4$ & $27.3 \pm 4.1$ & $31.4 \pm 3.5$ \\
\hline Phagocytic index & $0.45 \pm 0.04$ & $0.51+0.05$ & $0.45 \pm 0.01$ & $0.66 \pm 0.03 *$ \\
\hline Phagocytic number & $1.84 \pm 0.04$ & $1.87 \pm 0.07$ & $1.9 \pm 0.06$ & $2.0 \pm 0.054$ \\
\hline Phagocytic capacity & $321.2 \pm 24.3$ & $318.9 \pm 36.0$ & $317.5 \pm 41.2$ & $320.8 \pm 44.2$ \\
\hline Lysozyme activity, \% & $38.6 \pm 6.1$ & $38.8 \pm 4.7$ & $48.2 \pm 5.5$ & $51.7 \pm 7.11$ \\
\hline Bactericidal activity, \% & $22.6 \pm 3.3$ & $20.5 \pm 1.9$ & $25.6 \pm 5.0^{*}$ & $26.1 \pm 3.8^{*}$ \\
\hline T-lymphocytes, \% & $59.3 \pm 5.2$ & $55.3 \pm 2.6$ & $63.7 \pm 4.6$ & $64.0 \pm 3.3$ \\
\hline B-lymphocytes, \% & $27.4 \pm 3.5$ & $27.1 \pm 5.2$ & $28.3 \pm 1.8$ & $28.6 \pm 2.0$ \\
\hline CEC & $58.5 \pm 6.7$ & $60.3 \pm 7.2$ & $58.6 \pm 5.4$ & $56.0 \pm 3.9$ \\
\hline
\end{tabular}

$* \mathrm{P}<0.05$ 
Thus, phagocytic activity in animals of the experimental group increased by $6.6 \%$ on the 30th day of the experiment, and by the end of the experiment - by $22.6 \%$ (in the control group, no changes in this indicator were noted).

Studies have found that in calves of the experimental group, the intensity of phagocytosis (phagocytic index) significantly increased $(\mathrm{P}<0.05)$ by 1.53 times relative to the background indicators and by 1.3 times relative to the control indicators.

An additional indicator of cellular immunity that characterizes the aggressiveness of white blood cells (the intensity of phagocytosis) is the phagocytic number. In the blood of calves of the experimental group receiving bentonite supplementation, the phagocytic number also increased by the end of the experiment and amounted to $2.0 \pm 0.054$ against $1.71 \pm 0.07$ background indicators and $1.87 \pm 0.07$ against control indicators $(116.9 \%$ and $108.7 \%$, respectively).

There were no significant differences in phagocytic capacity.

In addition, to assess the nonspecific humoral link of the immune system, we studied the age-related dynamics of changes in the lysozyme and bactericidal activity of the blood serum of calves participating in the experiment.

Based on the conducted experience, it was found that the lysozyme activity in calves of the experimental group increased by 1.6 times on the 30th day, and by 1.72 times on the 60 th day. In the control group, this indicator increased by $28.2-29.0 \%$, remaining at the level of $38.6 \pm 6.1-38.8 \pm 4.7 \%$ throughout the studies.

The state of natural resistance of the body is most fully characterized by the bacterial activity of the blood serum, which consists in the ability to suppress the growth of microorganisms and depends on the activity of all humoral factors of nonspecific resistance, being its integral expression.

As the results show, the percentage of bacterial activity of blood serum in the studied calves of the experimental and control groups had significant differences. In control animals, this indicator decreased by $13.5 \%$ during the experiment, while in the experiment there was a significant increase $(\mathrm{P}<0.05)$ in the bactericidal activity of serum by $8.0 \%$ by the 30 th day of the study and by $10.1 \%$ by the end of the experimental period. Differences in the indicators of bactericidal activity of calves of the experimental and control groups at the end of the experiment were $27.3 \%$.

When studying the magnitude of the relationship between bactericidal and phagocytic activity, a high degree of correlation $(\mathrm{r}=0.86)$ was established in experimental calves. In the control group, the correlation coefficient was slightly lower and was equal to 0.71 .

Studies of the cellular and humoral components of immunity found that the use of ekobentokorm contributed to an increase in the content of T-lymphocytes due to a decrease in zero cells (OK-lymphocytes). So, in the experimental group, the number of T-cells by the end of the experiment was $64.0 \pm 3.3 \%$, B-cells- $28.6 \pm 2.0 \%$, while in intact animals these indicators were at the level of $55.3 \pm 2.6 \%$ and $27.1 \pm 5.2 \%$, respectively. The difference between the groups was $15.7 \%$ and $5.5 \%$.

One of the functions of immunity is the removal of endo - and exogenous antigens from the body, which can be bacterial and viral agents, xenobiotics, abnormal proteins and other formations of immune complexes antigen-antibody. Immune complexes are involved in the mechanism of removal of antigens from the body.

In our case, the experimental animals had a decrease in circulating immune complexes (CIC) by $7.3 \%$ compared to the calves of the control group. Although this indicator was not found to be reliable in studies, a decrease in CIC in combination with other factors of nonspecific resistance indicates an activation of immunity, both cellular and humoral.

\section{Conclusions}


As a result of the study, it was found that ekobentokorm (TU 9283-199-10514645-13-2013) has a high biological activity, which is manifested by improving the morphological and biochemical parameters of the blood of cows, as well as increasing the milk productivity of cows. In calves of the black-and-white breed, positive dynamics were recorded in the indicators that characterize the natural resistance of the body. The use of ekobentokorm (TU 9283-199-10514645-13-2013) has a pronounced stimulating effect on the immunocompetent systems of the body, as a result of which the level of non-specific protection of the animal increases.

\section{References}

1. G.A. Zelenkova, I.F. Gorlov, Fodder bentonite for farm animals and a bird (ekobentokorm) TU 9283-199-10514645-13-2013 specifications https://www.elibrary.ru/item.asp?id=23201318 (Last accessed 2021/02.21)

2. A. Pahomova, S. Halász, A. Pakhomov, and et al., E3S Web of Conferences 217, 06002 (2020)

3. A. Zelenkov, G. Zelenkova, S. Tresnitskii, and et al., E3S Web of Conferences 217, 09010 (2020)

4. A. Pahomova, S. Halász, V. Fedorchuk, G. Zelenkova, A. Pakhomov, E3S Web of Conferences 210, 11003 (2020)

5. A. Zelenkov, A. Ermakov, G. Zelenkova et al., E3S Web of Conferences 135, 01088 (2019)

6. A. Zelenkov, A. Ermakov, G. Zelenkova et al., IOP Conf. Series: Earth and Environmental Science 403(1), 012020 (2019)

7. A. Zelenkov, G. Zelenkova, A. Ermakov et al., E3S Web of Conferences 164, 06032 (2020)

8. I.F. Gorlov, I.M. Osadchenko, D.V. Nikolaev, and et al. Method of fattening bullcalves (A23K 1/16, A23K 1/14) https://www.elibrary.ru/item.asp?id=37435767 (Last accessed 2021/02.21)

9. A. Pahomova, A. Pakhomov, and et al. Vitamin and mineral adsorption food additives for poultry and the method of its application (A23K 50/70, A23K 20/158, A23K 20/174) https://www.elibrary.ru/item.asp?id=37832316 (Last accessed 2021/02.21)

10. R.P. McDonnell, M.V.H Staines, Journal of Dairy Research 84(3), 240-247 (2017)

11. P. Rezamand, B.P. Hatch, K.G. Carnahan, M.A. Mcguire, Journal of Dairy Research, 83(1), 20-27 (2016)

12. M. Kuprys-Caruk, B. Chablowska, D. Kotyrba, and et all. Journal of Veterinary Research 62(1), 57-64 (2018)

13. A.P. Zelenkov, P.I. Zelenkov, G.A. Zelenkova. Vestnik OrelGAU, 3(54), 79-85 (2015)

14. A.I. Klimenko, Ye.V. Dushkin et all. Scientific Almanac of Black Sea Region Countries 3(3), 10-19 (2015)

15. A.I. Klimenko, A.P. Pakhomov et all. Scientific Almanac of Black Sea Region Countries 3(3), 1-9 (2015) 